\title{
Multilocular Lesion
}

National Cancer Institute

\section{Source}

National Cancer Institute. Multilocular Lesion. NCI Thesaurus. Code C41422.

A cystic lesion that has more than one compartment. 